\title{
Correction to: Harnessing digital workflows for the understanding, promotion and participation in the conservation of heritage sites by meeting both ethical and technical challenges
}

Mario Santana Quintero ${ }^{1 *}$, Reem Awad $^{1}$ and Luigi Barazzetti ${ }^{2}$

Correction to: Built Heritage

https://doi.org/10.1186/s43238-020-00005-7

In the original publication of this article (Quintero et al., 2020) the family name of the last author is incorrect. The correct family name of the last author should be Barazzetti rather than Barazetti. The original publication has been corrected.

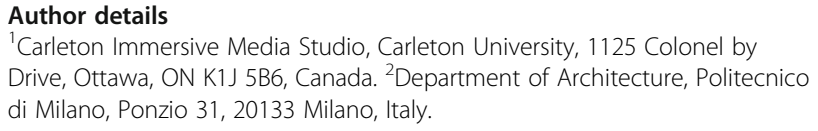

Published online: 19 April 2020

\section{Reference}

Santana Quintero M, et al. 2020. Built Heritage 4: 6. https://doi.org/10.1186/ s43238-020-00005-7.

\footnotetext{
The original article can be found online at https://doi.org/10.1186/s43238020-00005-7.

* Correspondence: Mario.santana@carleton.ca

${ }^{1}$ Carleton Immersive Media Studio, Carleton University, 1125 Colonel by

Drive, Ottawa, ON K1J 5B6, Canada

Full list of author information is available at the end of the article
}

\section{SpringerOpen}

๑ The Author(s). 2020 Open Access This article is licensed under a Creative Commons Attribution 4.0 International License, which permits use, sharing, adaptation, distribution and reproduction in any medium or format, as long as you give appropriate credit to the original author(s) and the source, provide a link to the Creative Commons licence, and indicate if changes were made. The images or other third party material in this article are included in the article's Creative Commons licence, unless indicated otherwise in a credit line to the material. If material is not included in the article's Creative Commons licence and your intended use is not permitted by statutory regulation or exceeds the permitted use, you will need to obtain permission directly from the copyright holder. To view a copy of this licence, visit http://creativecommons.org/licenses/by/4.0/. 